\title{
Case Series of Pterygium Excision and Conjunctival Autograft - No Suture, No Glue Technique and Review of Literature
}

\author{
Dr.G.Ravi Babu M.S ${ }^{1}$, Dr.B.Manjula M.S ${ }^{2}$, Dr.P.Ashakiran ${ }^{3}$ \\ ${ }^{1}$ Professor, Department Of Ophthalmology, GGH, Guntur. \\ ${ }^{2}$ Assistant Professor, Department Of Ophthalmology, GGH, Guntur. \\ ${ }^{3}$ Post Graduate, Department Of Ophthalmology, GGH, Guntur.
}

\begin{abstract}
Background: To evaluate the efficacy of blood clot fixation of the conjunctival autograft after pterygium excision in primary and recurrent pterygium.

Objective: To establish a simple, cost effective, less painful and less time consuming technique of conjunctival autograft at a tertiary govt .hospital, Department of Ophthalmology, Guntur, AP.

Design: Prospective analysis of hundred patients with primary and recurrent pterygium operated between October 2015-March 2016, recurrence and complications analyzed.

Materials And Methods: A total of 100 eyes from 100 patients with primary or recurrent nasal pterygium in age group 40-65 years were recruited. All eyes underwent pterygium excision followed by conjunctival autografting. Blood oozed during pterygium excision was used as tissue adhesive to secure conjunctival autograft. The mean duration of follow up is between 12-14 weeks with good primary out come with no recurrence was noted in all cases .

Results: After surgery, graft loss occured in 2 eyes(2\%) and chemosis in 4eyes(4\%)

Conclusion: Blood oozed during pterygium excision may provide novel approach for securing conjunctival autograft. Conjunctival autograft without glue or sutures appears to be an effective modality for primary and recurrent pterygium with no extra cost and full benifits to the patients.
\end{abstract}

Keywords: Pterygium, Conjunctival autograft, no glue, no suture, auto blood fibrin clot, recurrence.

\section{Introduction}

The term pterygium comes from the ancient Greek word $($ pteryx $)=$ wing and $($ gion $)=$ fin. Pterygium is characterized by a triangular portion of the bulbar conjunctiva encroaching onto the cornea. It is believed that pterygium is growth disorder characterized by conjunctivalisation of the cornea due to localized ultraviolet rays stimulated damage to the limbal stem cells. Destructive pterygial fibroblasts are also responsible for corneal invasion

Pterygium is more often seen in men than in women. This is attributed to the fact that males are exposed to dust and environmental irritants more than women. Usually seen within the interpalpebral fissure and most often on the nasal side. The nasal affinity of the pterygium is attributed to the following factors. Sparseness of the subconjunctival tissue in the temporal region, exposed to a lesser extent to UV radiation due to greater amount of bowing of outer $2 / 3$ of the upper lids. The prevalence rate of primary pterygium varies from 0.7 to $3.1 \%$ in various populations around the world. Patient may have foreign body sensation, discomfort, congestion (redness), irritation, grittiness, blurring of vision either because of induced astigmatism or obscuring visual axis.

Indications for surgery include cosmetic disfigurement, recurrent inflammation, interference with contact lens wear ,motility restriction and rarely, changes suggestive of neoplasia. But patient should be explained that there is fairly high risk of recurrence which may be more unsightly. To prevent recurrence conjunctival auto grafting either by use of fibrin glue or sutures is being used. In this study the possibility of blood ooze during the pterygium excision used as a tissue adhesive to secure the conjunctival autograft was studied.

\section{Method}

All the cases had informed written consent and hospital ethical committee approval for study.

\begin{tabular}{|l|l|}
\hline Number of eyes & 100 \\
\hline Primary pterygium & 94 \\
\hline Recurrent pterygium & 6 \\
\hline Male & 59 \\
\hline Female & 41 \\
\hline Mean age & $50+/-2$ yrs \\
\hline Mean surgical time & $20+/-0.9$ min. \\
\hline
\end{tabular}




\begin{tabular}{|l|l|}
\hline Follow up & $12-14$ weeks min 12 weeks \\
\hline
\end{tabular}

\section{Surgial Technique}

All patients were anaesthetized with a peribulbar block and then eyes were painted and draped. The fibrotic tissue was extensively dissected to expose the sclera and corneal stroma. The subconjuctival fibrovascular tissue, including tenon's capsule, were thoroughly removed to provide clean scleral bed. The size of the defect is measured with calipers. Around $0.5 \mathrm{~mm}$ more than the measured defect marking is done on supero temporal conjunctiva. A thin film of blood clot is allowed to form over the bare sclera. Any active bleeding is stopped by direct tamponade. A thin tenon free conjunctival auto graft with limbal stem cell is excised. Auto graft is slided over the cornea, orientation is kept limbus to limbus. It is slipped over with draping motion to ensure epithelial side is up. After placement of graft over the bare sclera with oozed blood during excision gently press for 3-5 minutes. The stabilization of graft is tested centrally and on each free edge to ensure firm adherence to sclera.At the end of surgery carefully eye speculum was removed without distorting graft.Eye is patched for 12-24 hours.

Routine post op instructions like tapered 1\% Prednisolone acetate eye drops 4-6 time daily for3-4 weeks, Moxifloxacin eye drops for 7 days .Lubricating eye drops for 6-8 weeks are used .Patients follow up for $1^{\text {st }}$ day, 1 week, 4 weeks and 12 weeks.
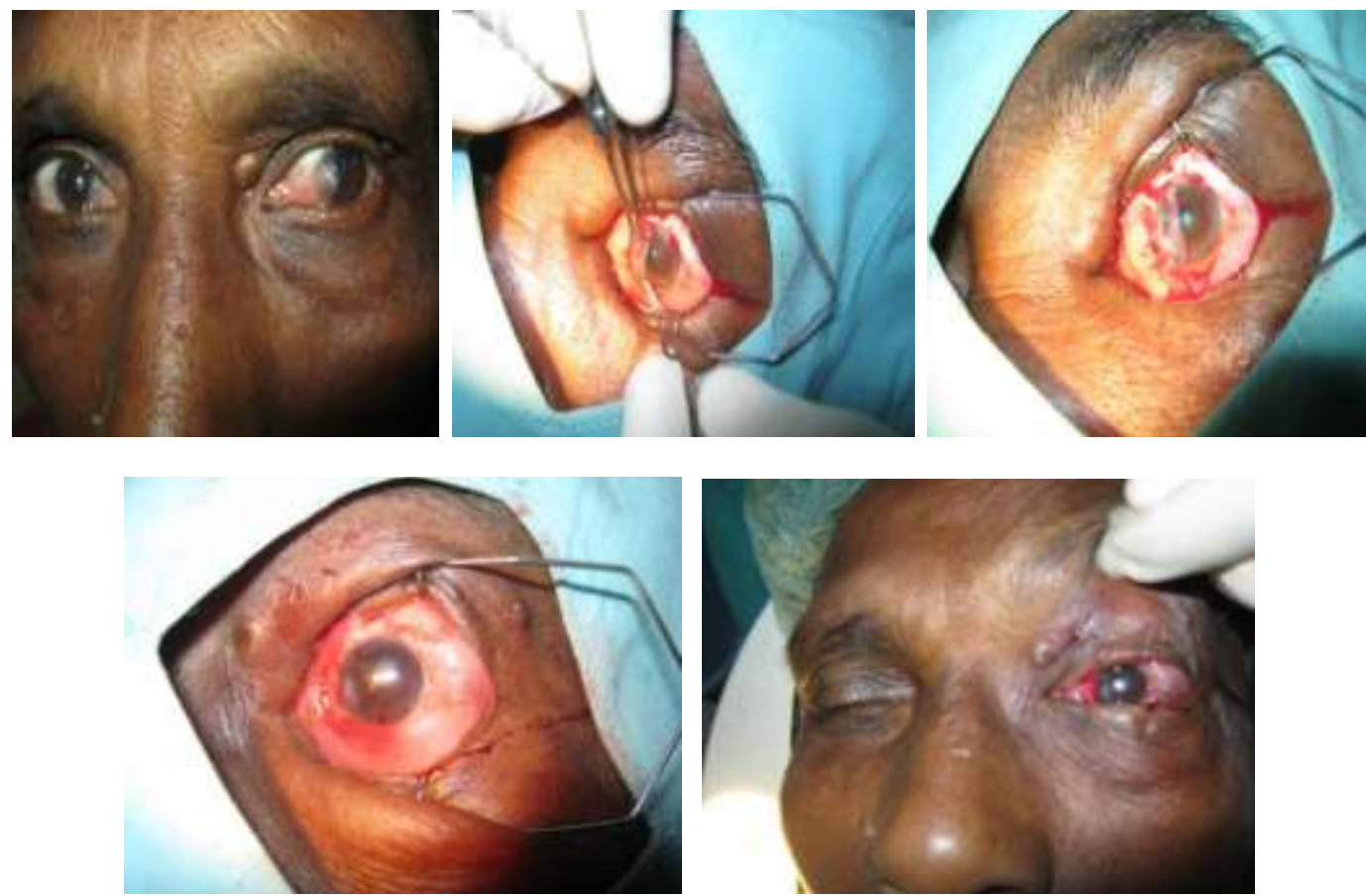

Results

\begin{tabular}{|l|l|l|}
\hline Primary outcome & & \\
\hline & Graft dislodgement & Nil \\
\hline & Recurrence & Nil \\
\hline Secondary out come & & \\
\hline & Post up & Pain minimum \\
\hline & cosmesis & Good \\
\hline Minor complications & & \\
\hline & Subconjunctival haemorrhage & 8 cases $(8 \%)$ \\
\hline & Graft recession & 5 cases $(5 \%)$ \\
\hline & Graft edema & 4 cases $(4 \%)$ \\
\hline
\end{tabular}

\section{Discussion}

Pterygium surgery should ideally have a low or no recurrence, minimal complications and be cosmetically acceptable. Current surgical methods to prevent pterygium recurrence include conjunctival autograft, and limbal- conjunctival transplant, conjunctival flap and conjunctival rotation autograft surgery, amniotic membrane transplant, cultivated conjunctival transplant, lamellar keratoplasty, and the use of fibrin glue. All of these techniques involve the use of sutures or fibrin glue and are therefore vulnerable to associated complications. 
Conjunctival autograft was popularized by Kenyon et al. The most common method of autograft fixation is suturing, with the drawbacks of prolonged operating time, postoperative discomfort, suture abscesses, granuloma formation and recurrence due to suture irritation.

The presence of sutures may lead to prolonged wound healing and fibrosis.

Although generally considered safe, fibrin glues are currently manufactured from human plasma and therefore carry theoretical risk of transmissible diseases. Use of patients own autologous blood was based on clotting mechanism of blood coagulation, but should be used before fibrinolysis occurs as blood clots naturally, was developed with all the drawbacks eliminated.

\section{Conclusions}

Autologous fibrin in blood is a useful alternative method for graft fixation in pterygium surgery, we found the new procedure of autografting free of any untoward complications.

\section{References}

[1]. Hirst L. distribution, risk factors and epidemiology in Taylor HR (edi) Pterygium Kugler publications the hagne Netherlands 2000; 2:15-28.

[2]. Immunohistochemical evidence that human pterygia originates from an invasion of vimentin. Expressing altered limbal epithelial basal cells- Dushka N Reid TN Cure En Res 1994; 13:473-481.

[3]. Hirst LW. The treatment of pterygium Surv. Ophthalmology 2003; 45:145-180.

[4]. Current concepts and techniques in pterygium treatment. Current opinion ophthalmology. Donald TH Tametal. 2007; 18(4):308318.

[5]. Hirst LW. Ophthal mology. 115(10), 1663-1672.

[6]. Morsi corsena $J$ et al.cornea Pterygium surgery conjunctival auto graft with fibrin adhesive 2006; 25:34-6.

[7]. Conjunctival auto grafting without fibrin glue or sutures for pterygium surgery- cornea - Singh PK et al.2013; 32(1):104-107.

[8]. Jaros PA, DeLuise VP. Pingueculae and pterygia. Surv Ophthalmol. 1988 Jul-Aug;33(1):41

[9]. Sebban A, Hirst LW. Pterygium recurrence rate at the Princess Alexandra Hospital. Aust N Z J Ophthalmol. 1991 Aug;19(3):203206

[10]. Kenyon KR, Wagoner MD, Hettinger ME. Conjunctival autograft transplantation for advanced and recurrent pterygium. Ophthalmology. 1985 Nov;92(11):1461-1470.

[11]. Lewallen S. A randomized trial of conjunctival autografting for pterygium in the tropics. Ophthalmology. 1989 Nov;96(11):16121614.

[12]. Rubinfeld RS, Pfister RR, Stein RM, Foster CS, Martin NF, Stoleru S, Talley AR, Speaker MG. Serious complications of topical mitomycin-C after pterygium surgery. Ophthalmology. 1992 Nov;99(11):1647-1654.

[13]. Farrell PL, Smith RE. Bacterial corneoscleritis complicating pterygium excision. Am J Ophthalmol. 1989 May 15;107(5):515-517.

[14]. Tarr KH, Constable IJ. Late complications of pterygium treatment. Br J Ophthalmol. 1980 Jul;64(7):496-505

[15]. MacKenzie FD, Hirst LW, Kynaston B, Bain C. Recurrence rate and complications after beta irradiation for pterygia. Ophthalmology. 1991 Dec;98(12):1776-1781.

[16]. Youngson RM. Recurrence of pterygium after excision. Br J Ophthalmol. 1972 Feb;56(2):120-125. $\square$ Thoft RA, Wiley LA, Sundarraj N. The multipotential cells of the limbus. Eye (Lond) 1989;3(Pt 2):109-113.

[17]. Vastine DW, Stewart WB, Schwab IR. Reconstruction of the periocular mucous membrane by autologous conjunctival transplantation. Ophthalmology. 1982 Sep;89(9):1072-1081. 